$10-1-1994$

\title{
Rethinking Constitutional Change
}

Edward A. Purcell Jr.

New York Law School, edward.purcell@nyls.edu

Follow this and additional works at: http://digitalcommons.nyls.edu/fac_articles_chapters

\section{Recommended Citation}

80 Virginia L. Rev. 1

This Article is brought to you for free and open access by the Faculty Scholarship at DigitalCommons@NYLS. It has been accepted for inclusion in Articles \& Chapters by an authorized administrator of DigitalCommons@NYLS. 
VOLUME 80

\section{VIR GINIA}

\section{LAW REVIEW}

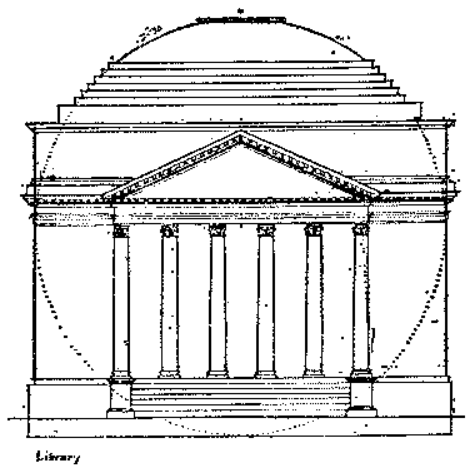

\section{RETHINKING CONSTITUTIONAL CHANGE}

Edward A. Purcell, Jr. 


\title{
RETHINKING CONSTITUTIONAL CHANGE
}

\author{
Edward A. Purcell, Jr.*
}

66 DTHINKING the New Deal Court"1 expands our understanding of a dominating event in American legal history. Professor Cushman's emphasis on the extent to which the supporters of the New Deal have managed to impose their interpretation on events is surely justified, as is his insistence that the Roosevelt administration's numerous mistakes helped precipitate the constitutional crisis. His claim about the importance of "lawyering" in understanding the crisis is equally warranted. Although his article raises numerous issues that merit discussion, space confines me to only a few.

\section{Doctrine and the Dynamics of Legai Change}

Professor Cushman's basic thesis is that Roosevelt's Court-packing plan neither caused nor influenced the Supreme Court's socalled "switch in time" and that the election of 1936 most likely had little or no impact on it. The argument is forcefully made and, for the most part, convincing. Its persuasiveness rests not just on the "negative" reasons advanced but, more fundamentally, on Professor Cushman's alternative explanation as to why the Court reached the decisions it did in the spring of 1937.

The Court's 1905 decision in Swift \& Co. v. United States, ${ }^{2}$ he has argued elsewhere, introduced the expansive "current of commerce" concept into Commerce Clause jurisprudence and, at the same time, cabined the concept's expansive potential by construing it in light of a rigid, if largely implicit, due process limitation. ${ }^{3}$ Dur-

* Professor of Law, New York Law School.

1 Barry Cushman, Rethinking the New Deal Court, 80 Va. L. Rev. 201 (1994).

2196 U.S. 375 (1905).

3 He argues that the Court limited the Commerce Clause by restricting the category of businesses that could "directly" affect interstate commerce-and hence businesses that fell within the scope of the commerce power-to those that were "affected with a public interest" within the sharply limited meaning of the Court's due process jurisprudence. See Barry Cushman, A Stream of Legal Consciousness: The Current of Commerce Doctrine from Swift to Jones \& Laughlin, 61 Fordham L. Rev. 105, 114-16 (1992). 
ing the next thirty years, two critical doctrinal developments occurred. First, the expansive potential of the "current of commerce" image gradually led the Court to see the commerce power as more broadly inclusive. Second, in Nebbia v. New York, ${ }^{4}$ decided in 1934, the Court abandoned the restrictive categorical method of analysis that it had used to limit state police powers under the Due Process Clause. ${ }^{5}$ The result was not only to expand the scope of state power but also, by shrinking the due process limit that Swift had placed on the Commerce Clause, to expand national power as well. The Court's 1937 decisions were "implicit in the internal logic of Swift and Nebbia," Professor Cushman maintains, and they were thus expansive but not revolutionary. That doctrinal evolution, in turn, provides twin supports for the argument he advances here: it explains why the "old" Court could hand down a series of decisions that upheld broad federal and state regulatory powers even in the absence of external political pressures; and, by establishing that there was no actual "switch" in 1937, it demonstrates that the election and Court-packing plan were necessarily without constitutional effect.

While the doctrinal argument is incisive, three interrelated considerations suggest its limits as a matter of historical explanation. First, however ill-fated the Court-packing plan might appear to later generations, it electrified Americans in early 1937. It was a stunning possibility raised at a volatile time by a triumphant and powerful President against an unpopular Court whose very legitimacy seemed in question. Second, it was not unrealistic for defenders of the Court to fear that the President and his staggering Democratic legislative majorities could, if Roosevelt's plan failed, strike at the Court indirectly but disruptively by using the congressional power over federal jurisdiction. The Democratic and progressive Congresses elected after 1930 had, after all, twice in the previous five years restricted the jurisdiction of the lower federal

4291 U.S. 502 (1934).

5 The Court declared that there was "no closed class or category of businesses affected with a public interest" and that the phrase meant no more than that "an industry, for adequate reason, is subject to control for the public good." Nebbia, 291 U.S. at 536, quoted in Cushman, supra note 3, at 130.

6 Cushman, supra note 3 , at 156 . 
courts in order to serve social and political goals. ${ }^{7}$ Third, there remains the question of personnel. Assuming that neither the "Four Horsemen" nor the three "progressive" Justices ${ }^{8}$ were influenced by outside pressures, and even assuming that Chief Justice Charles Evans Hughes was also unaffected, that still leaves the question of Justice Owen J. Roberts, the essential fifth vote for the 1937 decisions. 9 Was he wholly uninfluenced by outside pressures when he cast his pivotal votes? We will, of course, never know for sure, and the record that exists is exceptionally thin and inconclusive. ${ }^{10}$ We do know, however, that the Four Horsemen thought that Roberts had abandoned them. "What," asked one of them after he had voted to note probable jurisdiction in West Coast Hotel Co. v. Parrish, "is the matter with Roberts?" 12 We know, too, that on at least one occasion Roberts spoke as though he had felt the pressure in early 1937. Criticizing the Court-packing plan many years later, he acknowledged "the tremendous strain and the threat to the existing Court, of which I was fully conscious."13

These considerations help identify more specifically both what Professor Cushman's argument establishes and what it leaves open. On one side, he shows that the election generated little or no actual threat to the Justices and that the Court-packing plan quickly ran into huge if not wholly insurmountable obstacles to its passage.

7 See Johnson Act, 48 Stat. 775 (1934) (current version at 28 U.S.C. $\$ 1342$ (1988)); Norris-LaGuardia Act, 47 Stat. 70 (1932) (codified as amended at 29 U.S.C. $\$ \S 101-115$ (1988)).

8 The "Four Horsemen" were Justices Willis Van Devanter, James Clark McReynolds, George Sutherland, and Pierce Butler. The three "Progressives" were Justices Louis D. Brandeis, Harlan Fiske Stone, and Benjamin N. Cardozo.

9 For a standard-and unflattering-view of Roberts' career, see Alpheus T. Mason, Owen Josephus Roberts, in Supp. 5 Dictionary of American Biography 571, 573-76 (John A. Garraty ed., 1977).

10 See, e.g., Charles A. Leonard, A Search for a Judicial Philosophy: Mr. Justice Roberts and the Constitutional Revolution of 1937, at 136-57, 178-81 (1971).

11300 U.S. 379 (1937).

12 Memorandum from Justice Owen J. Roberts to Justice Felix Frankfurter [hereinafter Memorandum], quoted in Felix Frankfurter, Mr. Justice Roberts, 104 U. Pa: L. Rev. 311, 315 (1955). By voting with the progressive Justices to note probable jurisdiction in West Coast Hotel, Roberts seemed to signal his dissatisfaction with the Court's "liberty of contract" precedents. See id.

13 Composition and Jurisdiction of the Supreme Court: Hearings on S.J. Res. 44 Before the Subcomm. on Constitutional Amendments of the Senate Comm. on the Judiciary, 83rd Cong., $2 \mathrm{~d}$ Sess. 9 (statement of Justice Owen J. Roberts). 
Furthermore, he demonstrates that authoritative sources capable of logically supporting the Court's "switch" existed by at least 1934 . He thus effectively refutes the claim that the Court drastically changed its position when confronted by two specific political threats, and he shows further that the Court as an institution acted with formal integrity in 1937 . On the other side, however, he does not show that the Justices were impervious to the concentrating pressures they faced during the Depression and New Deal, and he does not show that the existence of potentially controlling precedents fully explains their decisions in 1937. Professor Cushman, in other words, does not refute the claim that a combination of "external" pressures-intensifying sharply after the election-may have nudged Hughes, and probably helped push Roberts, to invoke one possible set of authorities instead of another and to select one vector of interpretation to the exclusion of others. ${ }^{14}$ To show that a doctrinal passageway existed is important, but it is not to show why the individual Justices-particularly Justice Roberts in a five-tofour decision-chose to walk through it. ${ }^{15}$

\section{Internal Mechanisms of Doctrinal Change}

Professor Cushman's goal, of course, is not to show that doctrine "caused" the decisions of 1937 or to deny the relevance of social and political factors. Rather, he seeks to identify some of the failures of the "virtually monolithic externalist interpretation" that New Dealers and their later sympathizers imposed on the "constitutional revolution." 16 The "conventional" interpretation, he writes, "den[ies] the constitutional jurisprudence of the period any status as a mode of intellectual discourse having its own internal

14 He explains the Court's "anti-New Deal" decisions of 1935-1936, such as A.L.A. Schechter Poultry Corp. v. United States, 295 U.S. 495 (1935), essentially as aberrations attributable to a variety of factors, including the dubious nature of the specific statutes at issue and the abysmal lawyering of the Department of Justice. See Cushman, supra note 3, at $131-39$.

15 Professor Cushman acknowledges, in fact, that the Court-packing plan did seem to contribute-albeit indirectly and at massive and unnecessary cost-to the results Roosevelt sought. Congressman Sumner's bill to encourage judicial retirements "found new life" and passed within the month, he writes, "once the extreme measures contained in the President's bill had been proposed." Cushman, supra note 1, at 215. Apparently encouraged by the more attractive retirement package, two of the Four Horsemen retired during the next ten months, thereby allowing Roosevelt to reconstitute the Court.

16 Id. at 205. 
dynamic."17 Accordingly, he seeks to illuminate that internal dynamic by showing how a "structurally interdependent system of thought gradually unraveled" and played a significant role in a far more complex story than is generally told about the switch in time. ${ }^{18}$

$\mathrm{He}$ is surely right that "externalist" interpretations are partial and misleading when they fail to recognize the significance of "doctrinal categories" and their interrelationships. During the past two decades legal and constitutional historians have given close attention to law as a field of intellectual and cultural history, and scholars in all disciplines have increasingly stressed the importance of perspective and the problems of "interpretation."19 Professor Cushman contributes to that general development by examining in illuminating detail the intertwining of due process and Commerce Clause jurisprudence and by showing how their relationship generated an internal potential-probably against the wishes of many of the Justices-for sanctioning substantial increases in governmental regulatory powers.

More revealing than his examination of Swift's expansive potential, however, is his analysis of the way that the Court grafted the due process category of "business affected with a public interest" onto its Commerce Clause jurisprudence and thereby limited Swift's expansive potential. "The realities of a nationally integrated economy thus could be acknowledged by the Constitution," he explains, "without dismantling the categories of laissez-faire formalism or significantly altering the balance of intergovernmental

17 Id. at 206.

18 Id. at 261.

19 A bare and diverse sample of the burgeoning literature would include the following: Steven Connor, Postmodernist Culture (1989); Gadamer and Hermeneutics (Hugh J. Silverman ed., 1991); Carol Gilligan, In a Different Voice (1982); George Lakoff, Women, Fire, and Dangerous Things: What Categories Reveal About the Mind (1987); Howard Margolis, Paradigms and Barriers: How Habits of Mind Govern Scientific Beliefs (1993); New Directions in American Intellectual History (John Higham \& Paul K. Conklin eds., 1979); Janice A. Radway, Reading the Romance: Women, Patriarchy, and Popular Literature (1984); Richard Rorty, Philosophy and the Mirror of Nature (1979); Vision and Method in Historical Sociology (Theda Skocpol ed., 1984); Robert W. Gordon, Legal Thought and Legal Practice in the Age of American Enterprise, 1879-1920, in Professions and Professional Ideologies in America 70 (Gerald L. Geison ed., 1983); Duncan Kennedy, Toward an Historical Understanding of Legal Consciousness: The Case of Classical Legal Thought in America, 1850-1940, 3 Res. L. \& Soc'y 3 (1980). 
authority."20 Professor Cushman's analysis not only shows the intertwining of due process and Commerce Clause jurisprudence, but it also illustrates the blending of social context, legal consciousness, formal doctrine, and judicial purpose that was characteristic of the Court in the late nineteenth and early twentieth century. $\mathrm{He}$ illustrates the Court's tendency to think in relatively rigid categorical terms, while he also shows that "laissez-faire formalism" did not function apart from either the judges' sense of context or their consideration of purpose. ${ }^{21}$ On one level, most of the Justices probably believed that their categories and doctrines reflected essential truths about the nature of human society; on another level, they appreciated how the categories and doctrines formed a jurisprudence that was both logically coherent and socially prudent; and on a third level, they recognized that that jurisprudence served the central values of their own culturally rooted visions of the good society. Those melded perspectives helped underwrite the distinctive jurisprudence of the late nineteenth and early twentieth century, and Professor Cushman's analysis isolates a classic example of the intellectually ordered and culturally purposeful law shaping that marked an era. ${ }^{22}$

\footnotetext{
20 Cushman, supra note 3 , at 116 .

21 The label "formalism". adds little to Professor Cushman's analysis and, as a general matter, adds little to our understanding of the "old" Court. The turn-of-the-century Justices were complex and sophisticated, and they were as sensitive to context and purpose as they were to the requirements of logic and doctrine. The idea of judicial "formalism" is more a product of twentieth-century intellectuals than of nineteenth- and early twentiethcentury judges. See William P. Lapiana, Logic and Experience: The Origin of Modern American Legal Education 128, 187 n.11 (1994); Edward A. Purcell, Jr., Litigation and Inequality: Federal Diversity Jurisdiction in Industrial America, 1870-1958, at 253-54, 396 n.15 (1992).

22 Morton. J. Horwitz has recently emphasized the extent to which judges in the "classical era" thought in terms of "bright-line classifications." See Morton J. Horwitz, The Transformation of American Law, 1870-1960, at 9-31 (1992). The turn-of-the-century Court, he explains insightfully:

was forced to support its suspicion of legislative motives by asserting that unless the question was really one of kind, involving an inherent category of things affecting health, there could be no real constitutional check on the legislature. Here was the intellectual process by which the categories of Classical Legal Thought became ever more essentialist ....

Id. at 30 .
} 


\section{RESPECIFYING THE "MOMENTS" OF Constitutional Change}

Denying that a doctrinal "revolution" occurred in 1937, Professor Cushman deflates the importance of that year and replaces the discarded "moment" with three new ones. The middle one, the Court's 1934 decision in Nebbia v. New York, unfortunately remains somewhat shrouded. Professor Cushman is quite clear on why Nebbia was doctrinally important-it rejected the "public/private" distinction and rendered all categories of business vulnerable to state and federal regulation..$^{23}$ The mystery that hovers, however, is how and why Roberts came to join Hughes and the three "progressives" in deciding Nebbia and, more importantly, how and why Roberts came to write an opinion that contained such a sweeping and potentially radical analysis. On those intriguing questions Professor Cushman does no more than hint at an unsatisfactory answer. From an "array of exceptions to what was arguably a general rule," he states, "Roberts distilled a general principle." 24

Professor Cushman's discussion of the other two moments is both more illuminating and more complete. He argues that $S$ wift in 1905 marked the beginning of a coherent doctrinal period and that the decisions of the "New Deal Court" in the early forties marked its end. ${ }^{25}$ The intervening forty years constituted an integrated period in which constitutional thought was shaped by a characteristic "set of doctrinal categories"26 which, after Roosevelt's appointments, were "abandoned by a generation of jurists with no stake in salvaging its remains." $27 \mathrm{He}$ is right in emphasizing the importance of both moments.

23 Cushman, supra note 3, at 127-31; Barry Cushman, Doctrinal Synergies and Liberal Dilemmas: The Case of the Yellow-Dog Contract, 1992 Sup. Ct. Rev. 235, 276-79. Professor Cushman would also emphasize the importance of other decisions from 1934, including, for example, Home Building \& Loan Ass'n v. Blaisdell, 290 U.S. 398 (1934) (narrowing the Contracts Clause).

24 Cushman, supra note 3 , at 130 . Professor Cushman, it must be noted, can hardly be blamed for not removing the shroud. There are apparently no private papers or other documents that illuminate the origins of Nebbia or mark out the path Roberts took in drafting his opinion.

25 See id. at 156-60.

26 Cushman, supra note 1 , at 258 .

27 Id. at 261 . 
As to the earlier one, the years from the turn of the century to the First World War witnessed a major reorientation in federal law and the role of the national judiciary, and $S$ wift was a classic product of the time. The reorientation emerged from the Court's inchoate determination to follow two closely related and balanced policies: first, to recognize the need for and legitimacy of expanded government regulation, especially at the national level; and, second, to protect the sometimes-conflicting values of liberty, property, federalism, and national economic integration by ensuring that regulatory activities were limited and that judicial remedies against their abuse-especially federal judicial remedies-were available. ${ }^{28}$ The Court reshaped federal law across the board: constitutional provisions such as the Bill of Rights ${ }^{29}$ and the Four-

\footnotetext{
28 See Purcell, supra note 21, at 265-91. Announcing what the Court apparently regarded as a fallback position from its general policy of ensuring the widespread availability of federal judicial remedies for allegedly unconstitutional government actions, the Court declared in 1908 that, if the Eleventh Amendment were ever to preclude a federal court from hearing a federal constitutional challenge to a state action, the Constitution obligated the states to provide judicial forums to bear such a claim. See General Oil Co. v. Crane, 209 U.S. 211, 226-27 (1908). For a discussion of the expansion of remedies under general federal jurisdiction, see, e.g., Michael G. Collins, "Economic Rights," Implied Constitutional Actions, and the Scope of Section 1983, 77 Geo. L.J. 1493, 1507-1529 (1989).
}

.29 See, e.g., Chicago, B. \& Q.R.R. v. Chicago, 166 U.S. 226 (1897) (imposing the limitations of the Fifth Amendment's Takings Clause on the states through the Due Process Clause of the Fourteenth Amendment); Hale v. Henkel, 201 U.S. 43 (1906) (holding that the protection against unlawful searches and seizures offered by the Fourth Amendment extended to corporations); Twining v. New Jersey, 211 U.S. 78, 99, 110 (1908) (stating that rights protected by the first eight amendments may be safeguarded against state action if they fall within the fundamental conception of due process, but emphasizing that the core principles of due process were "singularly few").

Twining provides a particularly revealing example of the Court's hierarchy of values in the years after the turn of the century. Specifically, the decision held that the SelfIncrimination Clause of the Fifth Amendment was not made binding on the states by virtue of the Fourteenth Amendment. See Twining, 211 U.S. at 113-14. The right that the defendants claimed to be free from compelled self-incrimination, the opinion explained, was not encompassed within the fundamental guarantees of due process. Carefully and sharply, it distinguished the narrow scope of due process in such an area of "procedure," id. at 111 , from "the effect of due process in restraining substantive laws, as, for example that which forbids the taking of private property for public use without compensation," id. at 110 . The two realms, Twining stressed, were entirely different. The right to be free from compelled self-incrimination "cannot be ranked with ... the inviolability of private property." Id. at 113. As for the values of "Iiberty and justice," the Court continued, they were far better served by recognizing "[t] $]$ he power of the people of the States to make and alter their laws at pleasure," id. at 106, rather than by having "their capacity for sober and 
teenth Amendment, ${ }^{30}$ statutes covering such areas as antitrust ${ }^{31}$ and railroad regulation, ${ }^{32}$ federal remedial law involving injunc-

restrained self-government weakened by forced construction of the Federal Constitution," id. at 114. Thus, in Twining substantive due process protection for property appeared to be one of the highest values (along with the right to a hearing and the right to be free from "arbitrary power," id. at 113), followed by a conjoined "liberty/federalism" value. Both surpassed in importance the "personal" right, id. at 99 , to be free from compelled selfincrimination, a right that rested not on "an unchangeable principle of universal justice" but merely on "a law proved by experience to be expedient," id. at 113 .

Twining also suggests the complexities of the Court's role and the multivalued nature of the law it developed. Twining was, after all, not merely a "criminal" case but also an "economic regulation" case. It involved the prosecution of two bank directors who gave false information to state bank examiners with the intent to misrepresent the financial condition of their bank. Id. at 79 (statement of the case). Thus, in denying their selfincrimination claim and affirming their conviction, the Court was supporting the state's efforts to regulate its banks. Moreover, by refusing to impose constitutional restrictions on state criminal procedure, it was recognizing an important area where state citizens "may, if they choose, alter [the law] by legislation." Id. at 114. The mere fact that Twining emphasized the high value of "property," in other words, did not mean that it was necessarily inconsistent with "regulation," and the mere fact that it refused to incorporate the right against compelled self-incrimination into the Fourteenth Amendment did not mean that it devalued individual "liberty," only that it discriminated among a range of important liberties.

30 See, e.g., Lochner v. New York, 198 U.S. 45 (1905) (voiding a state law limiting the hours that bakers could work as a violation of the substantive guaranties of the Fourteenth Amendment); Muller v. Oregon, 208 U.S. 412 (1908) (upholding the constitutionality of a state Iaw that limited the hours that women could work in factories). Together, Lochner and Muller established that legislatures could "regulate" business to protect public health or safety as long as they could show-to the satisfaction of the Court-that the legisiation was not in reaity an attempt to assist one "class" at the expense of others and that a significant connection existed between the enactment and the-protection of public health or safety. See generally Howard Gillman, The Constitution Besieged: The Rise and Demise of Lochner Era Police Powers Jurisprudence 114-46 (1993); Alpheus T. Mason, Brandeis: A Free Man's Life 247-53 (1946).

31 See the series of decisions from Addyston Pipe \& Steel Co. v. United States, 175 U.S. 211 (1899) (upholding the power of Congress to limit "freedom of contract" when acting under the Commerce Clause), to Standard Oil Co. v. United States, 221 U.S. 1 (1911) (establishing that restraints of trade that were judicially determined to be "reasonable" did not violate the Sherman Antitrust Act). See generally Martin J. Sklar, The Corporate Reconstruction of American Capitalism, 1890-1916 (1988); Rudolph J. Peritz, The "Rule of Reason" in Antitrust Law: Property Logic in Restraint of Competition, 40 Hastings L.J. 285 (1989).

32 See, e.g., Johnson v. Southern Pac. Co., 196 U.S. 1 (1904) (construing the federal Safety Appliance Act broadly to implement the congressional intent to protect the safety of railroad workers and passengers); Texas \& Pac. Ry. v. Abilene Cotton Oil Co., 204 U.S. 426 (1907) (holding that the power of the Interstate Commerce Commission to set railroad rates preempted claims under state law alleging that rates were unreasonable or discriminatory); Texas \& Pac. Ry. v. Rigsby, 241 U.S. 33, 41 (1916) (construing the federal Safety Appliance Act to preempt state regulation in the area and to imply a private cause 
tions ${ }^{33}$ and habeas corpus, ${ }^{34}$ and a wide range of relatively arcane procedural matters including res judicata, ${ }^{35}$ pendent jurisdiction, ${ }^{36}$ shareholder derivative suits, ${ }^{37}$ the removability of state condemna-

of action under the statute for an injured worker, while declaring that the "plenary" power of Congress under the Commerce Clause extended sweepingly to areas not "wholly unrelated" to interstate travel). With regard to the Court's treatment of congressional efforts to provide tort remedies to injured railroad workers, compare The Employers' Liability Cases, 207 U.S. 463 (1908) (holding the First Federal Employers' Liability Act unconstitutional on the ground that it was not limited to interstate commerce) with Second Employers' Liability Cases, 223 U.S. 1 (1912) (upholding the constitutionality of the Second Federal Employers' Liability Act, which was narrowed to reach only interstate commerce).

33 See In re Debs, 158 U.S. 564 (1895) (implicitly recognizing a constitutional cause of action under the Commerce Clause for injunctive relief against a railroad strike in order to protect the United States mail); Ex parte Young, 209 U.S. 123 (1908) (implicitly recognizing a constitutional cause of action under the Fourteenth Amendment for injunctive relief against the efforts of a state official to enforce an allegedly unconstitutional state law).

${ }^{34}$ See, e.g., The Japanese Immigrant Case, 189 U.S. 86 (1903) (declaring that the command of due process limited the authority of government immigration officials even when they acted under statutes that made their decisions final); Frank v. Mangum, 237 U.S. 309 (1915) (declaring that federal habeas corpus relief could be available to state prisoners on due process grounds even if the jurisdiction of the state court was not challenged); see also Henry M. Hart, Jr., The Power of Congress to Limit the Jurisdiction of Federal Courts: An Exercise in Dialectic, 66 Harv. L. Rev. 1362, $1390 \mathrm{n} .85$ (1953) (bighlighting the significance of the Japanese Immigrant Case). See generally Ann Woodhandler, Demodeling Habeas, 45 Stan. L. Rev. 575 (1993) (describing the historical development of habeas corpus).

35 See, e.g., Deposit Bank v. Frankfort, 191 U.S. 499 (1903) (holding that federal law, not state law, determined the res judicata effects of federal court decisions ruling on matters of federal law); see also Stephen B. Burbank, Interjurisdictional Preclusion, Full Faith and Credit and Federal Common Law: A General Approach, 71 Cornell L. Rev. 733, 747-53 (1986) (discussing pre-1938 Supreme Court decisions concerning the preclusive effects of federal judgments).

36 See Siler v. Louisville \& N.R.R., 213 U.S. 175 (1909) (holding that, in deciding cases arising under federal law, the federal courts could not only decide related state law claims-even in the absence of diversity of citizenship-but could also withhold judgment on the federal claims and decide the case solely on the basis of state law).

${ }^{37}$ See, e.g., Corbus v. Alaska Treadwell Gold Mining Co., 187 U.S. 455 (1903) (holding that a suit asserting a corporation's right could only be brought by the corporation, but recognizing that shareholders who made a demand upon the directors to bring such an action for the corporation and were ignored could then bring a derivative action in the corporation's name); Doctor v. Harrington, 196 U.S. 579 (1905) (holding that the doctrine of corporate citizenship, based on the presumption that all shareholders were citizens of the incorporating state, did not destroy jurisdiction based on diversity of citizenship when shareholders brought a derivative suit against their corporation); see also Herbert Hovenkamp, Enterprise and American Law, 1836-1937, at 45-47 (1991) (discussing the Court's treatment and the significance of shareholder derivative suits). 
tion proceedings, ${ }^{38}$ and the relationship between the need to exhaust state remedies and de novo access to the federal courts. ${ }^{39}$ Central to the process, the Court reoriented the role of the lower federal courts, turning them away from cases presenting state law issues in disputes between private parties and toward cases presenting federal law issues and disputes over government regulation. ${ }^{40} \mathrm{Swift}$, as Professor Cushman perceptively reveals, exemplified the implementation of those twin policies in the jurisprudence of the Commerce Clause, and the tension between the fluid image of a "current of commerce" and the rigid category of "business affected with a public interest" illustrated the kind of tensions that the policies unavoidably generated. ${ }^{41}$ In ensuring its ability to review and channel expanded governmental activities, the Court in Swift and its many analogues was reacting not merely to accelerating social change and proliferating government regulation. It was also reacting to its own decisions that legitimated those expanded governmental activities and thereby heightened the Justices' concern with controlling them-especially the activities of the states-

38 See Madisonville Traction Co. v. Saint Bernard Mining Co.; 196 U.S. 239 (1905) (holding that a state court proceeding to review and confirm condemnation awards was removable even though condemnation was a special prerogative of the state and the controlling state statute provided that the proceeding take place in the local county court).

39 See Prentis v. Atlantic Coast Line Co., 211 U.S. 210, 230 (1908) (assuring parties who wished to challenge state regulatory actions in the federal courts that, although required to exhaust state administrative remedies, they could ultimately bring any federal law challenge to the state's final decision in a federal court where they would be free of res judicata effects from any state proceeding); Bacon v. Rutland R.R., 232 U.S. 134 (1914) (applying Prentis and allowing a party who had exhausted state administrative remedies to challenge the state's administrative ruling in federal court). Although Prentis is usually cited for its requirement that parties must exhaust state administrative remedies, its ruling concerning the subsequent availability of a federal judicial forum is ultimately its more significant aspect. See, e.g., New Orleans Public Service, Inc. v. Council of New Orleans, 491 U.S. 350 (1989) (reaffirming the Prentis right of access doctrine even when the party seeking access to the federal court had, when the district court initially abstained, added its federal law claim to a pending state judicial proceeding challenging the state's administrative action on state law grounds).

40 Purcell, supra note 21, at 282-91.

41 Cushman, supra note 3 , at 114-16. In Prentis, for example, the Court required a federal plaintiff to exhaust state administrative remedies by pursuing a special appeal to Virginia's highest court as part of the state's established "legislative" rate-setting procedure, while at the same time it assured the plaintiff that, when the state's "legislative" appeal process was completed, a federal court would still be available to hear a de novo "judicial" challenge to the state's final action free of any res judicata effects from the judgment of the state courts. See Prentis, 211 U.S. at 230. 
by developing judicially enforceable limits and expanding the availability of judicial remedies. ${ }^{42}$

On Professor Cushman's third and last moment, the early 1940s, he is equally sound. If the decisions of 1937 failed to qualify as a "constitutional revolution," the body of rulings that shortly followed them surely did. The half dozen years between 1937 and 1943 effected major changes in American law and government. ${ }^{43}$ They witnessed not merely a "constitutional revolution" in the construction of the Commerce Clause and the Fourteenth Amendment, for example, but also a "Copernican revolution" 4 _initiated in 1938 by Erie R.R. v. Tompkins ${ }^{45}$ and the new Federal Rules of Civil Procedure-in the relationship between state and federal law. Neither half of that second revolution is fully comprehensible without recognizing the salience of the first, and the far-reaching consequences of both were in the hands of the "Roosevelt" Justices. They did constitute, as Professor Cushman states, "a [new] generation of jurists" 46 who brought profoundly different perspectives, assumptions, and values to the Court and, as a result, substantially restructured the nation's law within a relatively few years.

The juxtaposition of those two concurrent revolutions draws us back, ironically, to none other than Justice Roberts and the question of his "switch" in 1937. Defending his allegedly inconsistent votes in Morehead v. New York ex rel. Tipaldo $o^{47}$ and West Coast Hotel, Roberts maintained that he voted to invalidate a minimumwage law in the former not because he believed it unconstitutional but because he was convinced that he could not uphold it without overruling the Court's 1923 decision in Adkins v. Children's Hospi$t_{a l}{ }^{48}$ He was fully prepared to overrule Adkins, too, he declared, but the State's posture before the Court precluded him from doing

\footnotetext{
42 The Court has continued in the twentieth century to use similar "blocking categories" in areas, such as the First Amendment and the Equal Protection Clause, where it seeks to provide special protections against legislative and executive action.

43 C. Herman Pritchett, who regarded the 1941-1942 term as "a turning point for the Roosevelt Court," counted 28 pre-1937 decisions that the Court overruled between 1937 and 1947. See C. Herman Pritchett, The Roosevelt Court 300-01 (1948).

44 Paul A. Freund, On Law and Justice 224 (1968).

45304 U.S. 64 (1938).

46 Cushman, supra note 1 , at 261.

47298 U.S. 587 (1936).

48261 U.S. 525 (1923).
} 
so. "The State had not asked that the Adkins case be overruled but that it be distinguished," Roberts explained. "I was unwilling to put a decision on any such ground."49 Blocked by the State's position from overruling Adkins, he maintained that he had no choice but to apply the precedent and hold the statute unconstitutional.

In Erie, the Court overruled Swift v. Tyson, ${ }^{50}$ a decision older than Adkins, more frequently applied than Adkins, and as controversial as Adkins. There, too, the appellant sought only to distinguish Swift, not to have it overruled. The appellant expressly assured the Court that "[w]e do not question the finality of the holding of this Court in Swift v. Tyson." 51 Indeed, it actually defended the precedent, insisting that "the persistent criticisms of Swift $v$. Tyson and succeeding cases have been largely misdirected." 52 Notwithstanding the appellant's firm and unequivocal position, Roberts ignored it and joined four other Justices in overruling the ninety-six-year-old precedent on constitutional grounds. ${ }^{53} \mathrm{He}$ cast his vote in Erie less than two years after Tipaldo.

Two possibilities suggest themselves. One, of course, is that his vote in Erie shows that Roberts, contrary to his later claim about Tipaldo, was prepared to overrule precedent even when the parties before the Court failed to call for such action. Erie may suggest, then, that there is yet another reason to doubt the explanation he offered for his oft-debated "switch." ${ }^{4}$ The other possibility is that

49 Memorandum, supra note 12, quoted in Frankfurter, supra note 12, at 314.

50 41. U.S. (16 Pet.) 1 (1842).

51 Brief for Appellant, Erie, 304 U.S. 64 (No. 367), reprinted in Frederick C. Hicks, Materials and Methods of Legal Research 391, 412 (3d rev. ed. 1942).

52 Id. at 411.

53 The Court's action in overruling Swift even though the appellant had not requested such action and even though the issue had not been briefed struck a number of commentators as improper. See, e.g., T.A. Cowan, Constitutional Aspects of the Abolition of Federal "Common Law" 1 La. L. Rev. 161, 173 (1938). Justice Butler made the same point in his dissent. See Erie, 304 U.S. at 82 (Butler, J., dissenting).

54 For example, Roberts states that he informed Justice Butler, who wrote for the majority in Tipaldo, that "I would concur in any opinion which was based on the fact that the State had not asked us to re-examine or overrule Adkins." Memorandum, supra note 12, quoted in Frankfurter, supra note 12, at 314. Yet, Roberts also states that the Four Horsemen "expressed some surprise at my vote" to note probable jurisdiction in West Coast Hotel. Id. at 315 . If Roberts had expressed his view so clearly to Butler only one year earlier, why would the Four Horseman have been surprised at Roberts' vote to bring 
Roberts felt so badly burned by the criticism that his "switch" had sparked that he decided he would not again allow such a technical consideration as a narrowly framed appeal to block a major ruling otherwise desirable on the merits. Either inference, however, supports the more general proposition that Roberts was responsive to outside criticism, and either inference suggests, in turn, that Roberts was likely influenced by the acute pressures that were focused on the Court during the Depression and New Deal. However directly or indirectly felt, those pressures still seem a major reason why Roberts chose to walk through the fatal doctrinal passageway in Nebbia and West Coast Hotel, whether he made his truly decisive choice in 1934 or 1937.

\section{CONClusion}

The depth and clarity of Professor Cushman's doctrinal argument should not be taken to suggest that constitutional change is always and primarily a matter of legal categories and intellectual history. The special challenge of writing the legal history of doctrine arises precisely from the fact that judicial decisions reflect inherent tensions between norm, rule, theory, formality, and generality on the one hand and context, expedience, practicality, informality, and specificity on the other. The relative importance of those elements, and the relationships between them, are constantly in flux, and the balances that different courts and judges strike at different times are diverse and contingent. Professor Cushman shows us why the trained world view of the judge as interpreter should always be central to any historical, as opposed to legal, study of constitutional change, but he does not thereby embrace a narrow doctrinalism that would avoid the cultural and social complexities of legal and constitutional history. He has, accordingly, added significantly to our understanding of the New Deal Court.

up West Coast Hotel, a case that presented a direct challenge to Adkins? Moreover, the Court's opinion in Tipaldo contains particularly strong language reflecting a relatively rigid "liberty of contract" orientation. That language does not square with Roberts' proffered ground for joining the majority's opinion. Indeed, Roberts himself acknowledged that his explanation for his vote in Tipaldo did not seem consistent with the opinion's language. "My proper course," he admitted, "would have been to concur specially on the narrow ground I had taken. I did not do so." Id. He offered no explanation for his failure to concur separately. See id; see also Kenneth S. Davis, F.D.R.: Into the Storm, 1937-1940, at 98 (1993) (noting that "there was every reason why [Roberts] should not [concur], assuming him to be as hostile to Adkins as his testimony implies"). 


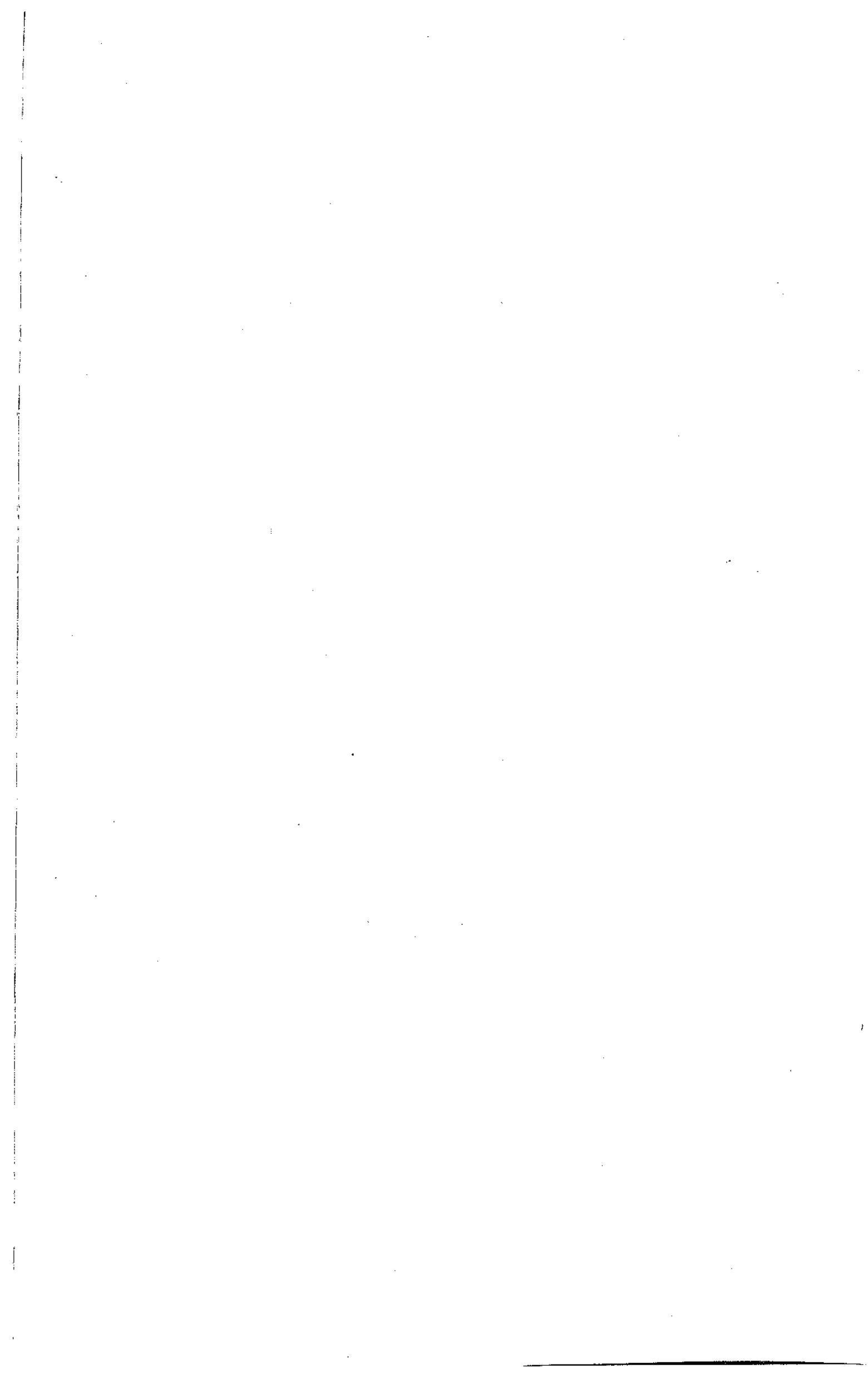

